ppi $201502 Z U 4645$

Esta publicación cientifica en formato digital es continuidad de la revista impresa ISSN-Versión Impresa 0798-1406 / ISSN-Versión on line 2542-3185Depósito legal pp

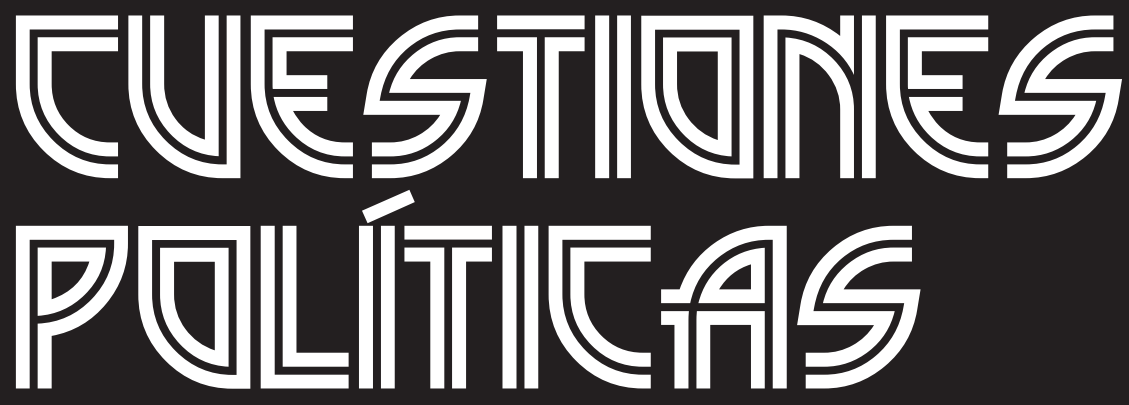

Instituto de Estudios Políticos y Derecho Público "Dr. Humberto J. La Roche' de la Facultad de Ciencias Jurídicas y Políticas de la Universidad del Zulia Maracaibo, Venezuela
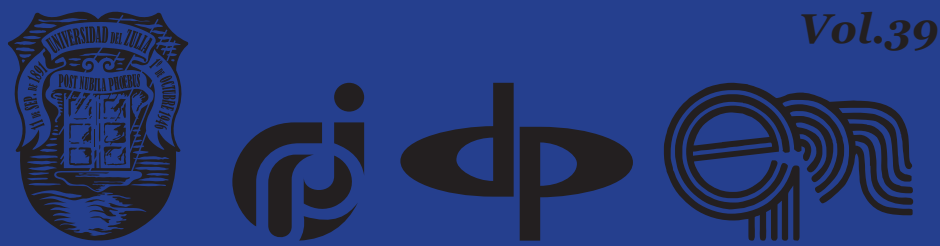


\title{
Criminal Aspects of Robotics Applications
}

\author{
DOI: https://doi.org/10.46398/cuestpol.3968.38
}

\author{
Fedor Romanovich Sundurov * \\ Ildar Rustamovich Begishev ** \\ Zarina Ilduzovna Khisamova *** \\ Igor Izmailovich Bikeev **** \\ Elvira Yuryevna Latypova ${ }^{* * * *}$ \\ Timur Radikovich Ishbuldin ******
}

\section{Abstract}

Direct and indirect criminological risks of the use of robotics are analyzed and issues of responsibility of the manufacturer (developer)and/or owner (user) of robotics are discussed for acts committed with their participation. This essay discusses promising areas of legal research related to robotics and its corresponding legal regulations. The definition of robotics is based and proposed as all categories of robots in their broadest sense, regardless of their purpose, degree of danger, mobility or autonomy, as well as cyberphysical systems with artificial intelligence in any form. It is proposed to recognize socially dangerous acts committed with the use of robotics as crimes committed in a generally dangerous way, if there are grounds for doing so. It is concluded that the commission of acts through robotics is capable, in certain cases, of creating a plurality of crimes in the form of a real aggregate. The expanding powers of State security bodies, which can

\footnotetext{
* Professor in Law, Faculty of Law, Department of Criminal Law, Kazan Federal University, Kazan, Russia (Russian Federation). ORCID ID: https://orcid.org/oooo-0oo1-9871-1924. Email: kafedra. ksu@yandex.ru

** Ph. D. in Law, Senior Researcher, Kazan Innovative University named after V.G. Timiryasov, Kazan, Russia (Russian Federation). ORCID ID: https://orcid.org/oooo-0001-5619-4025. Email: begishev@ mail.ru

*** Ph. D. in Law, Department of Planning and Coordination of Research Activities, Head, Research Department, Krasnodar University of the Ministry of Internal Affairs of the Russian Federation, Krasnodar, Russia (Russian Federation). ORCID ID: https://orcid.org/oooo-0003-0561-8718. Email: alise89@inbox.ru

**** Doctor of Law, Department of Criminal Law and Procedure, Kazan Innovative University named after V.G. Timiryasov, Kazan, Russia (Russian Federation). ORCID ID: https://orcid.org/oooo-0002-13654615. Email: bikeev@ieml.ru

***** Ph. D. in Law, Department of Criminal Law and Procedure, Kazan Innovative University named after V.G. Timiryasov, Kazan, Russia (Russian Federation). ORCID ID: https://orcid.org/oooo-0002-73904962. Email: elatypova@ieml.ru

****** Master of Law Laboratory Assistant, Department of Criminal Law and Procedure, Kazan Innovative University named after V.G. Timiryasov, Kazan, Russia (Russian Federation). ORCID ID: https:// orcid.org/oooo-0003-3102-1931. Email: t.ishbuldin@yandex.ru
}

Recibido el 15/10/2020 Aceptado el 08/02/2021 
carry out the functions of state policy development, legal regulation, control and supervision in the field of robotics application, have been verified.

Keywords: robotics; digital technologies; legal regulation; criminal liability; Artificial intelligence.

\section{Aspectos criminales de las aplicaciones robóticas}

\section{Resumen}

Se analizan los riesgos criminológicos directos e indirectos del uso de la robótica y se discuten las cuestiones de responsabilidad del fabricante (desarrollador) y/o propietario (usuario) de la robótica por los actos cometidos con su participación. Este ensayo discute las áreas prometedoras de la investigación jurídica relacionadas con la robótica y su normativa legal correspondiente. La definición de robótica se fundamenta y propone como todas las categorías de robots en su sentido más amplio, independientemente de su finalidad, grado de peligro, movilidad o autonomía, así como los sistemas ciber-físicos con inteligencia artificial en cualquier forma. Se propone reconocer los actos socialmente peligrosos cometidos con el uso de la robótica como delitos cometidos de forma generalmente peligrosa, si existen fundamentos para ello. Se concluye que la comisión de actos mediante la robótica es capaz, en determinados casos, de crear una pluralidad de delitos en forma de agregado real. Se ha comprobado la ampliación de las competencias de los órganos de seguridad del Estado, que pueden llevar a cabo las funciones de desarrollo de la política estatal, la regulación legal, el control y la supervisión en el campo de la aplicación de la robótica.

Palabras clave: robótica; tecnologías digitales; regulación legal; responsabilidad penal; Inteligencia artificial.

\section{Introduction}

Robotics both around the world and in Russia, directly correlates not only with the introduction and use of digital technologies in production, but also opens up new opportunities for the spread of threats to law and order and national security. The progress of digital technologies is an order of magnitude faster than the reaction of legislation and prevention from law enforcement agencies.

In our opinion, a special advantage for committing criminal offenses with the use of robotics is a triad of reasons, including: 


\section{Fedor Romanovich Sundurov, Ildar Rustamovich Begishev, Zarina Ilduzovna Khisamova, Igor Izmailovich Bikeev, Elvira Yuryevna Latypova y Timur Radikovich Ishbuldin

- simplicity and ease of use of robotic devices.

- anonymity or lack of physical contact between the subject and the instrument of the crime - the robot.

- the speed of implementation and operation of robotic devices.

Why do we emphasize speed? In answering this question, we will probably refer to a professional in his field, the most "media person" in the field of robotics - Elon Musk, the founder and head of Tesla: "Speed is the perfect weapon. And I don't mean the speed of my cars. It is about the speed of robots and the speed of their creation and renewal" (Forbes, 2018: s/p). In this regard, it is difficult to disagree with this opinion, since now no one is impressed by robots - vacuum cleaners and window cleaners, since the creation of absolutely anthropomorphic or, from a physiological point of view, humanoid robots is coming to the fore.

\section{Materials and methods}

The materials for the work were articles posted in scientific journals and on sites on the Internet.

The methodological basis of the study is a systematic approach to the study of complex, multidimensional phenomena, which is traditional for Russian researchers. When processing the factual material, a set of scientific research methods were used, namely abstract-logical, comparison, content analysis and correlation analysis.

\section{Results and discussion}

The problem of criminal-legal regulation of relations in the field of application of robotics both in foreign countries and in the Russian Federation remains unresolved at the moment. In this regard, it is necessary to develop a set of measures to prevent negative, socially dangerous manifestations of the use of robotics and the norms governing the state response to them.

Based on the foregoing, we believe it is necessary to supply the following problem in this area: are there mechanisms for legal regulation of robotics? (Begishev and Khisamova, 2018).

Let us analyze attempts to legislatively regulate robotics issues.

Science fiction writers and various scientists since the last century have made attempts to "write the laws of activity" of robotics. The most famous of them are A. Azimov with his "Three Laws of Robotics" (Asimov, 1942), one of the leaders of the world famous Microsoft company - S. Nadella 
and its "Ten Laws Of Artificial Intelligence" (Boyle, 2016) and, in fact, K. Chapek - the creator the word "robot" (Čapek, 1920). From the point of view of the latter, for example, the relationship between humanity and robotics will have to be regulated by some international judicial organization that equally recognizes both the robot and the person as a subject of law.

Their ideas, many of which are controversial, are very important for understanding the problem, but have not received legal development. And social reality, in particular the field of robotics, needs regulation, including criminal law.

There have also been attempts at self-regulation by scientists who are directly related to the creation of robotics. So, in 2017, when it became obvious that the issue requires regulatory legal regulation, almost four thousand scientists in this field signed the so-called "Twenty-three Azilomar Principles" (Asilomar AI Principles, 2017) of the International Institute for Future Generations, among which, for example, the following: benefit, controllability, reliability, rejection of the "arms race" with the help of robotics, safety for others and ethical responsibility of the creator.

This concept of principles, of course, does not carry any normative content, however, this is still a laudable attempt by the creators of robotics to develop common approaches, as well as to draw attention from government authorities to the need to resolve these issues. As a result, there began, albeit a Brownian, movement on the part of various states towards a normative legal understanding of new phenomena.

In the same year, bills on the issues under consideration appear in four states at once. The leaders are the Russian Federation, the People's Republic of China, the Federal Republic of Germany, and the Republic of Estonia. The latter, in our opinion, very hastily decided to become a pioneer in this area and gained a bitter experience by legalizing the rules "On the movement of robots - couriers"'. As a result, quite soon, the Baltic police had to identify and suppress the activities of robots - drug couriers.

Among international organizations, the first, at the beginning of 2018, to develop the project "On Robotics and Artificial Intelligence" began the advisory body of the European Union - the European Parliament, which in a couple of months adopted the corresponding Resolution ${ }^{8}$.

The legal personality of this body is very specific, since, despite the use of the word "Parliament" in its name, its acts are always advisory in nature, since only the European Commission has normative powers, which

7 Courier robots law. Estonian Law on Amendments to the Road Traffic Act. URL: https://robopravo.ru/ estonskii_zakon_o_robotakhkurierakh

8 European Parliament resolution of 16 February 2017 with recommendations to the Commission on Civil Law Rules on Robotics (2015/2103(INL)). URL: https://www.europarl.europa.eu/doceo/ document/TA-8-2017-0051_EN.html 
Fedor Romanovich Sundurov, Ildar Rustamovich Begishev, Zarina Ilduzovna Khisamova, Igor Izmailovich Bikeev, Elvira Yuryevna Latypova y Timur Radikovich Ishbuldin

600

Criminal Aspects of Robotics Applications

did not react to this Resolution in any way, citing the fact that its exclusive competence of the Member States of the European Union.

The most acceptable from the lawmaking and law enforcement point of view for the Russian Federation, albeit with certain reservations, are two initiatives in this area. First, this is a draft federal law prepared by D.S. Grishin, the founder of Grishin Robotics, one of the leaders of the Mail.Ru Group ${ }^{9}$ company, and secondly, this is the Model Convention on Robotics and Artificial Intelligence from the Research Center for Problems of Regulation of Robotics and $\mathrm{AI}^{10}$. The basis for these developments was the three "laws - principles" of robotics A. Azimov formulated in the last century:

1. A robot cannot harm a person or, by its inaction, allow harm to a person;

2. The robot must obey all orders given by a person, except for those cases when these orders are contrary to the First Law;

3. The robot must take care of its safety to the extent that it does not contradict the First or Second Laws (Asimov, 1942).

Based on the analysis of these proposals, we see that their authors propose the following - the creation on the basis of the three named rules new ones concerning the interaction of robots and robotics with other objects and subjects.

Comparing the animal and robotics, they point to the possibility of the latter to perform certain independent actions, declare that creation of a Unified State Register of Robotics, application of legal liability norms to the owner and (or) user of a source of increased danger in the event of a tort from robotics. However, at the same time, the question is debatable, according to what criterion this or that robotics will be classified as sources of increased danger.

The authors identify the following forms of possible options for the activity of robotics, which seems to be socially dangerous:

- designing a killer robot specifically for committing an offense;

- disabling software and hardware functions that block the possibility of harm to humans;

- designing a robot that can harm a person;

- designing a robot without realizing that it can be used to harm humans ${ }^{11}$. 
In this regard, we also consider it important to cancel that some issues related to the regulatory regulation of robotic devices are already being resolved at the state level ${ }^{12}$.

A particular example of robots - unmanned aerial vehicles (hereinafter referred to as UAVs) are already regulated by law, which is good news. So, for example, in case of violation of the rules for the use of UAVs and UAVs, administrative liability is provided, and in cases of photo and video filming with the help of these robotic devices, one can become accused in cases of high treason and the like.

However, this is only the first step in the framework of criminal regulation of aspects of the use of unmanned vehicles (robotic vehicles) (Korobeyev and Chuchaev, 2018; Chuchaev, 2019; Korobeyev and Chuchaev, 2019; Chuchaev and Malikov, 2019).

We also consider it necessary to note that the issue of amending the legislation on the issues under consideration is already ripe. A more detailed and in-depth regulatory regulation of the issue is needed than is done in the already existing regulatory legal acts and their projects. From an engineering point of view, metrics and standards should be developed to determine the level of intellectualization of robotics.

From a legal point of view, including from a criminal law point of view, it is necessary to work out a number of issues, among which the most important are the following:

1. conceptual and categorical apparatus of robotics;

2. mechanism for resolving issues of responsibility for committing socially dangerous acts using robotics;

3. criminological risks of using robotics;

4. identification, suppression, disclosure and prevention of socially dangerous acts related to robotics;

5. identification and identification of persons who have committed or are preparing these acts.

With regard to the terminological apparatus, we propose to amend the international standard ISO 8373: 2012 "Robots and robotic devices Vocabulary"13 and the national standard of the Russian Federation adopted in accordance with it GOST R 60.0.0.4-2019 / ISO 8373: 2012 "Robots and

12 Resolution of the Government of the Russian Federation of May 25, 2019 No. 658 "On approval of the Rules for accounting for unmanned civil aircraft with a maximum take-off weight of $0.25 \mathrm{~kg}$ to $30 \mathrm{~kg}$ imported into the Russian Federation or manufactured in the Russian Federation" // SZ RF. 2019. No. 22. Art. 2824 .

13 ISO 8373:2012. Robots and robotic devices - Vocabulary. URL: https://www.iso.org/standard/5589o. html 
Fedor Romanovich Sundurov, Ildar Rustamovich Begishev, Zarina Ilduzovna Khisamova, Igor Izmailovich Bikeev, Elvira Yuryevna Latypova y Timur Radikovich Ishbuldin

602

Criminal Aspects of Robotics Applications

robotic devices. Terms and definitions"14: to replace the concepts of robot and robotic devices with one more comprehensive category of robotics - all categories of robots (including smart robots, UAVs, UAVs, robotic agents, robotic mechanisms and cyber-physical systems, including those with artificial intelligence) in their broadest sense, regardless of their purpose, degree of danger, mobility or autonomy, as well as cyber-physical systems with artificial intelligence in any form, regardless of the presence of an indication in the name of the concept of "robot" and related (Naumov and Neznamov, 2017).

The use of a general category to designate the specified list of mechanisms seems to be useful for jurisprudence, since it clearly defines the scope of the required legal regulation, which is characterized by a certain isolation and autonomy. In our opinion, it will also be in demand in criminology, since it is able to isolate a segment of crime, which has great specificity. In addition, the above standards were put into effect in 2012 and changed only once - in 2016, although the most intense peak in the development of robotics began in 2017. Based on this, it is easy to understand that the field of robotics has "gone" far ahead of these standards.

There are two approaches to legal liability and issues related to the liability of robotics:

1. Objectively imputed responsibility - the ability to bear robots of a high level of development - with the legal status of an electronic person, responsible for the tort caused by them when they make decisions autonomously or otherwise independently interact with third parties (Khisamova and Begishev, 2019).

2. Risk management approach (responsibility of a person who could minimize risks). Responsibility should be proportional to the actual level of instructions given to the robot and the level of its autonomy. This is complemented by compulsory insurance of robot users and the creation of a compensation fund (Khisamova and Begishev, 2019).

In our opinion, approaches of this kind associated with a departure from the classical domestic system of recognition of robotics and artificial intelligence as a subject of law, and attempts to endow these phenomena with legal personality in the near future have no prospects for practical implementation (Sukhodolov et al., 2020; Bikeev et al., 2019; Khisamova et al., 2019; Begishev et al., 2020; Simmler and Markwalder, 2019; Khisamova et al., 2019; Simmler, 2019; Hallevy, 2010; Kirpichnikov et al., 2020). 
The actualization of issues related to criminal liability for committing socially dangerous acts with the use of robotics, unfortunately, correlates with the already existing real practice of causing harm to society. The first example was the collision of a woman with an unmanned vehicle (hereinafter - BTS) of the UBER company in early 2018 in the United States of America (Hallevy, 2015). Among the most widespread use of robotics for committing crimes, both in terms of the number of units and the damage caused, is the example of the use of UAVs and UAVs by illegal armed formations of the Republic of Yemen for the massive bombing of oil refineries - strategic and critical facilities of the Kingdom of Saudi Arabia ${ }^{15}$.

This example shows how and how, at minimal cost, a criminal can get the most beneficial effect for himself. In this example, the entire oil production of the Kingdom of Saudi Arabia, which is strategically important and budget-forming for it, was cut by half for a week. In addition, this attack caused damage to other objects: there were human casualties, other material losses.

We also agree with the fear expressed by the director of the FSB of Russia A.V. Bortnikov, which states that international terrorist and other extremist organizations in the near future will more intensively use robotics to achieve their goals (Bergen and Newcomer, 2018).

The following methods of relatively primitive use of robotics also pose significant dangers:

1. the use of BTS for the implementation of a terrorist act - hitting pedestrians in crowded places by initial programming it, for example, a car.

2. violation of information and other infrastructure.

3. the use of already existing anthropomorphic robots purchased both legally and on the black market.

4. the use of military or converted from civilian into military exoskeletons.

5. other cases of illegal use of robotics.

Based on the above examples, it is worth recognizing that robotics is a very specific instrument for committing crimes. Since robotics is recognized as a source of increased danger, we consider it necessary to recognize

15 Attack on oil facilities in Saudi Arabia: what we know. URL: https://www.bbc.com/russian/news49709610 
Fedor Romanovich Sundurov, Ildar Rustamovich Begishev, Zarina Ilduzovna Khisamova, Igor Izmailovich Bikeev, Elvira Yuryevna Latypova y Timur Radikovich Ishbuldin

604

Criminal Aspects of Robotics Applications

socially dangerous acts ${ }^{16}$ committed with the use of robotics as crimes committed in a generally dangerous way. This approach will directly affect the qualification of crimes, for example, under Part 2 of Art. 105 of the Criminal Code of the Russian Federation, in which this method is directly named in the disposition as a qualifying feature of the act.

If there is no indication in the norm of this method, we propose, when imposing punishment by the court for intentional crimes committed with the use of robotics, to take this circumstance into account as an aggravating feature under clause " $k$ " Part 1 of Art. 63 of the Criminal Code of the Russian Federation: "committing a crime using specially manufactured technical means", regardless of who and when the robotics was created.

Taking into account the fact that digital technologies are used in robotics, then for certain manipulations with it, responsibility under Art. 274 and 274.1 of the Criminal Code of the Russian Federation (Egorov, 2018).

The presence in the criminal law of separate norms providing for liability for crimes in the field of computer information (Ibragimov and Suragina, 2017), in our opinion, should not exclude the possibility of criminal prosecution for committing socially dangerous acts with the use of robotics, since situations may arise in which there will be multiplicity of crimes in the form of a real aggregate.

It should be noted that many crimes can be committed using the capabilities of robotics:

- socially dangerous acts infringing on human life and health.

- socially dangerous acts that infringe on the constitutional rights and freedoms of man and citizen.

- socially dangerous acts that infringe on public relations, protect the economy from criminal encroachments.

- socially dangerous acts that infringe on state power, service, and their interests.

- $\quad$ socially dangerous acts that infringe on public safety and public order.

- socially dangerous acts that infringe on the foundations of the constitutional order and the security of the state, etc.

When deciding who should be responsible for harm caused by the use of robotics, we believe unequivocally that the manufacturer (developer) and

16 Resolution of the Plenum of the Supreme Court of the Russian Federation dated January 26,2010 No. 1 "On the application by courts of civil legislation regulating relations on obligations due to harm to the life or health of a citizen" // Rossiyskaya Gazeta. 2010. No. 24 . 
(or) the owner (user) of robotics will be liable, of course, only in cases of subjective imputation of guilt.

However, already today, robotics of a new generation has a rather complex technological architecture, consisting of many software and hardware complexes, or it can be created using open-source codes (Begishev and Bikeev, 2020). In the situations considered, establishing the manufacturer (developer) and owner (user) of robotics is increasingly difficult. To overcome these difficulties in law enforcement, it seems possible to establish a system of standardization and certification of activities for the creation and commissioning of robotics (Tsukanova and Skopenko, 2018).

It is believed that the basis for resolving these issues will be the expansion of the powers of the Federal Security Service of the Russian Federation, namely, such a subdivision as the Service of Special Communications and Information, which will also carry out the functions of developing state policy, regulatory and legal regulation, control and supervision in the field of the application of robotics, the preparation of legislation in the field of the creation and use of robotics, the development of legal models for preventing the criminal behavior of robotics, in particular, the determination of the criminological risks of its use (Begishev and Khisamova, 2018).

We argue for this provision by the fact that in the practice of foreign countries, for example, in the United States of America, the rule on the control and regulation of issues related to robotics and artificial intelligence is already widely applied. Service of Special Communications and Information and the National Security Agency - a division of the US Department of Defense, which is part of the intelligence community as an independent intelligence agency, engaged in electronic reconnaissance and protection of electronic communication networks - are very identical bodies from a general functional point of view, we believe that the regulation of such relations in the Russian Federation on the part of the Service of Special Communications and Information will be fully justified and correspond to the meaning of the existence of this structure (Khisamova and Begishev, 2019; Bokovnya et al., 2019; Begishev et al., 2020; Begishev et al., 2019; Bokovnya et al., 2020; Begishev et al., 2019; Bokovnya et al., 2020; Bokovnya et al., 2020; Bokovnya et al., 2020).

\section{Summary}

Having analyzed the trends in the field of creation and use of robotics, we came to the conclusion that it is necessary to highlight two criminological risks inherent in this activity - direct (direct) and mediated (indirect) (Begishev and Khisamova, 2018). 
Fedor Romanovich Sundurov, Ildar Rustamovich Begishev, Zarina Ilduzovna Khisamova, Igor Izmailovich Bikeev, Elvira Yuryevna Latypova y Timur Radikovich Ishbuldin

Criminal Aspects of Robotics Applications

1. The immediate criminological risk of using robotics is a risk that directly correlates with the effect on a person and a citizen of a particular danger caused by the use of robotics.

These risks include:

- intentional commission of a socially dangerous encroachment on human life and health by a robotic device; freedom, honor, and dignity of the individual; constitutional human and civil rights and freedoms; public safety; peace and security of mankind, which entailed socially dangerous consequences, as well as other public relations protected by criminal law from criminal encroachments.

- deliberate actions with software, which is an integral and integral part of the use of a robotic device, resulting in socially dangerous consequences.

2. Indirect criminological risk in the use of robotics - the risk associated with unintended hazards in the context of the use of robotic devices.

These risks include:

- random errors in the software of the robotic device (errors made by the manufacturer (developer) of robotics);

- errors made by a robotic device in the course of its operation (errors made by robotics).

Proceeding from the foregoing, the thesis put forward by a number of scientists about the existence of high criminological risks of the use of robotics, consisting both in the intellectual technology itself and in the weak theoretical elaboration of the issue both in jurisprudence as a whole and in the sciences of the criminal cycle (Begishev and Khisamova, 2018), is confirmed.

\section{Conclusions}

Summing up the research carried out, we will formulate its main final provisions.

The promising areas of legal research related to robotics and the corresponding legal regulation are highlighted.

The definition of robotics is substantiated and proposed as all categories of robots in their broadest sense, regardless of purpose, degree of danger, mobility or autonomy, as well as cyber-physical systems with artificial intelligence in any form, regardless of the presence of an indication in the name of the concept of "robot" and related to it ... The use of this category 
seems to be useful for jurisprudence, since it clearly defines the specific area of the required legal regulation. In our opinion, it will also be in demand in criminology, since it is able to single out a separate segment of crime.

It is proposed to recognize socially dangerous acts committed with the use of robotics as crimes committed in a generally dangerous way, if there are grounds for that.

It is concluded that the commission of acts using robotics is capable, in certain cases, of creating a plurality of crimes in the form of a real aggregate.

Expansion of the powers of the Service of Special Communications and Information, which can carry out the functions of developing state policy, legal regulation, control and supervision in the field of robotics application, has been substantiated.

The direct and indirect criminological risks of using robotics are analyzed, and the issues of responsibility of the manufacturer (developer) and (or) owner (user) of robotics for acts committed with its participation are discussed.

At the same time, we consider it important to note that other legal aspects of the regulation of robotics issues, such as the identification, suppression, disclosure and prevention of socially dangerous acts related to robotics, as well as the identification and identification of persons who committed or prepare these acts, form a new model legal regulation of public relations in the area under consideration, as well as enrich from a theoretical and practical point of view the science of the criminal cycle: criminal law, criminology, operational investigative activities, criminalistics, prosecutorial supervision, penal law and criminal procedure.

\section{Acknowledgements}

The work is performed according to the Russian Government Program of Competitive Growth of Kazan Federal University.

\section{Bibliographic References}

ASIMOV, Isaac. 1942. Runaround. Astounding Science Fiction. New York, USA.

BEGISHEV, Ildar R; BIKEEV, Indesa. I. 2020. Crimes in the field of digital information circulation. Kazan: Publishing house "Knowledge" of Kazan Innovation University. Kazan, Russia.

BEGISHEV, Ildar R; KHISAMOVA, Zarina I. 2018. "Criminological Risks of Using Artificial Intelligence” In: All-Russian criminological journal. Vol. 12, No. 6, pp. 767-775. 
Fedor Romanovich Sundurov, Ildar Rustamovich Begishev, Zarina Ilduzovna Khisamova, Igor Izmailovich Bikeev, Elvira Yuryevna Latypova y Timur Radikovich Ishbuldin

608

Criminal Aspects of Robotics Applications

BEGISHEV, Ildar R; KHISAMOVA, Zarina I; MAZITOVA, Guzel I. 2019. "Criminal Legal Ensuring of Security of Critical Information Infrastructure of the Russian Federation" In: Revista Gênero \& Direito. Vol. 8, No. 6, pp. 283-292.

BEGISHEV, Ildar R; KHISAMOVA, Zarina I; MAZITOVA, Guzel I. 2019. Information Infrastructure of Safe Computer Attack. Helix, Vol. 9, Vol. 5, pp. 5639-5642.

BEGISHEV, Ildar R; KHISAMOVA, Zarina I; NIKITIN, Sergio. 2020. “The Organization of Hacking Community: Criminological and Criminal Law Aspects" In: Vserossiiskii kriminologicheskii zhurnal = Russian Journal of Criminology. Vol. 14, No. 1, pp. 96-105.

BEGISHEV, Ildar R; LATYPOVA, ElviraYu; KIRPICHNIKOV, Danila V. 2020. "Artificial Intelligence as a Legal Category: Doctrinal Approach to Formulating a Definition” In: Actual Probs. Econ. \& L.. Vol. 14, No. 1, pp. 79-91.

BERGEN, Mark; NEWCOMER, Eric. 2018. Uber Halts Autonomous Car Tests After Fatal Crash in Arizona. Bloomberg. Available online. In: https:// www.bloomberg.com/news/articles/2018-03-19/uber-autonomouscar-involved-in-fatal-crash-in-arizona. Consultation date: 22/03/2020.

BIKEEV, Igor; KABANOV, Pavel; BEGISHEV, Ildar; KHISAMOVA, Zarina. 2019. Criminological risks and legal aspects of artificial intelligence implementation. Proceedings of the International Conference on Artificial Intelligence, Information Processing and Cloud Computing. Sanya, China.

BOKOVNYA, Alexandra Yu; BEGISHEV, Ildar R; KHISAMOVA, Zarina I; NARIMANOVA, Nelli Rashidovna; SHERBAKOVA, Lyudmila Mikhailovna. 2020. "Legal Approaches to Artificial Intelligence Concept and Essence Definition” In: Revista San Gregorio. Vol. 1, No. 41, pp. 325336.

BOKOVNYA, Alexandra Yu; KHISAMOVA, Zarina I; Begishev, Ildar R. 2019. "Study of Russian and the UK Legislations in Combating Digital Crimes” In: Helix. Vol. 9, No. 5, pp. 5458-5461.

BOKOVNYA, Alexandra Yu; KHISAMOVA, Zarina I; BEGISHEV, Ildar R; LATYPOVA, ElviraYu; NECHAEVA, Evgeniya V. 2020. Computer crimes on the COVID-19 scene: analysis of social, legal, and criminal threats. Cuestiones Políticas. Vol. 38, No. 66, pp. 463-472,

BOKOVNYA, Alexandra Yu; KHISAMOVA, Zarina I; BEGISHEV, Ildar R; SIDORENKO, Elina L; ILYASHENKO, Alexander N; MOROZOV, Andre 
Yu. 2020. "Global Analysis of Accountability for Fake News Spread About the Covid-19 Pandemic in Social Media" In: Applied Linguistics Research Journal. Vol. 4, No. 7, pp. 91-95.

BOKOVNYA, Alexandra Yu; KHISAMOVA, Zarina I; VASYUKOV, V.F; BEGISHEV, Ildar R. 2020. "Assessment of Potential Risks of Regional for Global Financial Security" In: Cuestiones Políticas. Vol. 38, No. 66, pp. 156-166.

BOYLE, Andre. 2016. Microsoft CEO Satya Nadella lays out 10 Laws of AI (and Human Behavior). GeekWire. Available online. In: https://www. geekwire.com//microsoft-ceo-satya-nadella-10-laws-ai/. Consultation date: $22 / 03 / 2020$

ČAPEK, KRUR. 1920. Rossum's Universal Robots. Praga, Czech Republic.

CHUCHAEV, Andrea. I. 2019. "Robomobiles and personal safety: criminal law problems” In: Criminalist. Vol. 1, No. 26, pp. 94-98.

CHUCHAEV, Arnedo I; MALIKOV, Serva V. 2019. "Responsibility for causing damage by a highly automated vehicle: state and prospects" In: Actual problems of Russian law. Vol. 6, No. 103, pp. 117-124.

EGOROV, Iildar. 2018. Attacks in the network and. Rossiyskaya Gazeta. Federal issue. Moscow, Russia.

EUROPEAN PARLIAMENT RESOLUTION. 2017. With recommendations to the Commission on Civil Law Rules on Robotics (2015/2103(INL)). Available online. In: https://www.europarl.europa.eu/doceo/ document/TA-8-2017-0051_EN.html. Consultation date: 22/03/2020.

FORBES. Laws of robotics. How to regulate artificial intelligence / A. Neznamov. 2018. Available online. In: https://www.forbes.ru/tehnologii/355757zakony-robototehniki-kak-regulirovat-iskusstvennyy-intellekt. Consultation date: 22/03/2020.

FUTURE OF LIFE INSTITUTE. 2017. Asilomar AI Principles. Available online. In: https://futureoflife.org/ai-principles/. Consultation date: 22/03/2020.

HALLEVY, Gabriel. 2010. "The criminal liability of artificial intelligence entitiesfrom science fiction to legal social control” In: Akron Intell. Prop. J. Vol. 4, pp. 171-201.

HALLEVY, Gabriel. 2015. Liability for Crimes Involving Artificial Intelligence Systems. Springer International Publishing. Springer, Germany. 
Fedor Romanovich Sundurov, Ildar Rustamovich Begishev, Zarina Ilduzovna Khisamova, Igor Izmailovich Bikeev, Elvira Yuryevna Latypova y Timur Radikovich Ishbuldin

610

Criminal Aspects of Robotics Applications

IBRAGIMOV, Rustam; SURAGINA, Elina. 2017. "Law of machines. How to bring a robot to responsibility" In: Corporate lawyer. Vol. 11, pp. 10-17.

KHISAMOVA, Zarina; BEGISHEV, I. R; SIDORENKO, Elina L. 2019. “Artificial Intelligence and Problems of Ensuring Cyber Security" In: International Journal of Cyber Criminology. Vol. 13, No. 2, pp. 564-577.

KHISAMOVA, Zarina; BEGISHEV, Ildar R. 2019. "Criminal Liability and Artificial Intelligence: Theoretical and Applied Aspects” In: Vserossiiskii kriminologicheskii zhurnal = Russian Journal of Criminology. Vol. 13, No. 4, pp. 564-574.

KHISAMOVA, Zarina; BEGISHEV, Ildar R. 2019. "Legal regulation of artificial intelligence / Z.I. Khisamova” In: Baikal Research Journal. Vol. 10, No. 2, pp. 2411-2423.

KHISAMOVA, Zarina; BEGISHEV, Ildar; GAIFUTDINOV, Ramil R. 2019. "On methods to legal regulation of artificial intelligence in the world" In: International Journal of Innovative Technology and Exploring Engineering. Vol. 9, No. 1, pp. 5159-5162.

KIRPICHNIKOV, Danila; PAVLYUK, Albert; GREBNEVA, Yulia; OKAGBUE, Hilary. 2020. Criminal Liability of the Artificial Intelligence. Available online. In: https:/www.e3sconferences.org/articles/e3sconf/ pdf/2020/19/e3sconf_btses2020_04025.pdf. Consultation date: 22/03/2020.

KOROBEYEV, Alexandr; CHUCHAEV, Albert I. 2018. "Unmanned vehicles equipped with artificial intelligence systems: problems of legal regulation" In: Asia-Pacific Region: Economics, Politics, Law. Vol. 20. No. 3, pp. 117132.

KOROBEYEV, Alexandr; CHUCHAEV, Albert I. 2019. "Violation of the safety of robotic vehicles as an independent socially dangerous act" In: Criminal law. Vol. 3, pp. 37-48.

NAUMOV, Vladimir B; NEZNAMOV, Alex. V. 2017. Model Convention on Robotics and Artificial Intelligence rules for the creation and use of robots and artificial intelligence. Law and Information: Questions of Theory and Practice. Collection of materials of the VII International Scientific and Practical Conference. Ser. “Electronic legislation”, pp. 210-220.

ROBOTICS AND ARTIFICIAL INTELLIGENCE REGULATORY PROBLEM RESEARCH CENTER. 2017. Courier robots law. Estonian Law on Amendments to the Road Traffic Act. Available online. In: https:// robopravo.ru/estonskii_zakon_o_robotakhkurierakh. Consultation date: $22 / 03 / 2020$. 
SIMMLER, Monika. 2019. Maschinenethik und strafrechtliche Verantwortlichkeit. Handbuch Maschinenethik. Springer VS. Wiesbaden, Germany.

SIMMLER, Monika; MARKWALDEr, Nora. 2019. "Guilty Robots? -Rethinking the Nature of Culpability and Legal Personhood in an Age of Artificial Intelligence" In: Criminal Law Forum. Vol. 30, No. 1, pp. 1-31.

SUKHODOLOV, Alexander P; BYCHKOV, Artur V; BYCHKOVA, Anna M. 2020. "Criminal Policy for Crimes Committed Using Artificial Intelligence Technologies: State, Problems, Prospects" In: Journal of Siberian Federal University. Humanities \& Social Sciences. Vol. 13, No. 1, pp. 116-122.

TSUKANOVA, Elena Yurievna; SKOPENKO, Oleg Romanovich. 2018. "Legal aspects of liability for harm caused by a robot with artificial intelligence" In: Questions of Russian and International Law. Vol. 8, No. 4A, pp. 4248. 

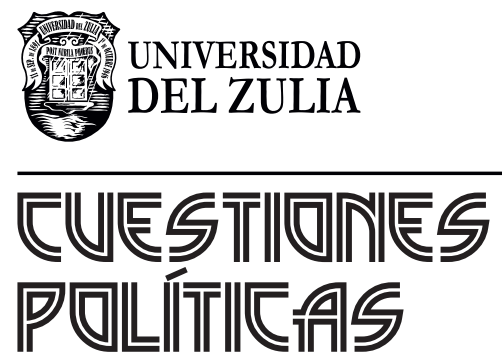

Vol.39 No 68

Esta revista fue editada en formato digital y publicada en enero de 2021, por el Fondo Editorial Serbiluz, Universidad del Zulia. Maracaibo-Venezuela 